\title{
O POMENIH POKRAJINE
}

\author{
Andrej Černe \\ Oddelek za geografijo Filozofske fakultete Univerze v Ljubljani, \\ Aškerčeva 2, SI - 1000 Ljubljana \\ e-mail: andrej.cerne@guest.arnes.si
}

Izvirni znanstveni članek

COBISS 1.01

\section{Izvleček}

$\mathrm{V}$ prispevku razpravljamo o pestrosti in raznovrstnosti geografskih konceptov, pristopov in izhodišč, ki jih uporabljamo geografi pri opredeljevanju pomenov pokrajine. $Z$ vidika pokrajine kot prostora in kraja ter na podlagi konceptov o specifičnosti, enkratnosti in individualnosti ter celovitosti, harmoničnosti in uravnoteženosti, smo prikazali različne možne poglede na pomene pokrajin kot predmeta geografskega proučevanja.

Ključne besede: geografski koncepti, prostor, pokrajina, kraj

\section{ABOUT THE SIGNIFICANCE OF LANDSCAPE}

\begin{abstract}
In the article we are discussing variety and diversity of geographical concepts, approaches and starting points, which geographers are using for the determination of significance of landscape. We described different possible aspects of significance of landscape as a subject of geographical research from the aspect of specificity, uniqueness, individuality, wholeness, harmony and balance.
\end{abstract}

Key words: geographical concepts, space, landscape, place 


\section{UVOD}

Geografi se pri proučevanju pomenov pokrajine ne moremo izogniti filozofskim in teoretičnim načinom znanja in vedenja, ki kažejo ne samo na to, kaj vemo, kakšno znanje imamo, marveč tudi kako smo do tega znanja prišli. Gre za prepletanje ontoloških in epistemoloških stališč, ki so podlaga različnim vrstam geografskih raziskav, saj so nujna sestavina našega razumevanja pokrajine. Naše ideje o pokrajini so vedno zgrajene v smislu različnih načinov gledanja, zaznavnih shem, konceptov in diskurzov. Na pokrajino gledamo iz številnih zornih kotov in zato so načini, kako jih opredeljujemo, metode, ki jo izberemo, konceptualni aparat, s katerim jih pojasnjujemo itd., odvisni od tega, od kod in iz katerega zornega kota jo gledamo. Problemi verjetno niso tam, kjer jih vidimo, ampak tam, od koder jih proučujemo. Zaradi te notranje pestrosti pogledov geografija pomembneje prispeva $\mathrm{k}$ opredeljevanju prostora.

\section{PRISTOPI IN IZHODIŠČA}

Izhodišča za ontološko diskusijo so raznovrstni, od minimalizma in dualizma, do pluralizma in nihilizma. Tradicionalni paradoksi družbenega razmišljanja se v bistvu nanašajo na: poseben - splošen; mikro - makro; delovanje - strukture; sobjektivnost - objektivnost. Platonsko-krščanska in novodobna-kartezijska tradicija je utrdila nasprotje duha in narave, duha in življenja, duše in telesa, zavesti in telesa kot način razumevanja sveta in samorazumevanja človeka (Plessner, 1981, 452).

Ontološki atomisti verjamejo, da je stvarnost sestavljena iz ločenih delov, ki med seboj vzajemno delujejo (medsebojno vplivajo), holisti pa trdijo, da je delovanje delov odvisno od njihovih razmerij z vsemi drugimi znotraj integriranega sistema. Medtem, ko nekateri materialisti verjamejo, da je ne-človeški svet notranje urejen, so drugi prepričani, da je nestabilen in kaotičen. Empiriki verjamejo, da »pomeni videti verjeti«, ne-empiriki pa prepričani, da je večji del stvarnosti očem neviden.

»Naivni realizem« trdi, da je geografska stvarnost (realnost) bolj ali manj takšna, kot je videti. $Z$ vidika realistične filozofije je pokrajina, ne glede na to, kaj je, v večji meri neodvisna od tega, kaj menimo, da je, in ni preprost produkt človekovega razuma. Na ta način obstaja pokrajina $v$ večji meri neodvisna od našega znanja o njej, naši opisi pokrajine pa ne, saj so v celoti odvisni od našega primernega znanja. Realistični empirizem trdi, da je pokrajina realna, da je tam zunaj, da jo zaznavamo s čuti, kakšna v resnici je, in v resnici je prostorska in časovna. Racionalizem pa temelji na predpostavki, da resnico zagotavlja razum, ne izkustvo, do kategorij ne pridemo z indukcijo iz izkustva, marveč so temeljne miselne oblike, ki nam šele omogočajo, da imamo izkustva. Ontološki pluralizem temelji na prepričanju, da obstaja mnoštvo realnih stvari, ki se jih ne da reducirati na dvojnost ali enost. Nasprotja med relativno objektivno, zunanjo podobo in relativno subjektivnimi notranjimi pogledi, predstavlja temeljno polarnost naše zavesti. S tega vidika bi lahko rekli, da obstajata dve pokrajini: fizični prostor - kar je dejansko »zunaj« in spodbuja naša čutila - in osebnostna pokrajina, ki jo doživljamo, in se pojavlja v našem umu. Dejstvo je, da je pokrajina tudi v nas in ne samo, da smo mi v pokrajini. Najpogosteje se kažejo težnja po zmanjševanju enega 
pristopa na račun drugega; vse tisto, kar je stvarno s subjektivnega vidika, lahko reduciramo na objektivni vidik ali obratno. Ta polarnost je značilnost pokrajine in temeljnega pomena za naše razumevanje prostora. Soočeni smo z relativno objektivnimi vidiki prostora kot zunanjega okolja in z relativno subjektivnimi vidiki naših izkušenj (posrednih in neposrednih), ki jih imamo s prostorom. Pokrajine vključujejo naše stvarne izkušnje s prostorom in tudi naše občutke o prostoru kot naravnem »objektu«. Obstajajo torej razhajanja med relativno subjektivnim, stvarnim občutkom o pokrajini in relativno objektivnim, naturalističnim konceptom o pokrajini. Težave pri kombiniranju stvarnih in naturalističnih pogledov na pokrajino odražajo polarnost med subjektivnim in objektivnim pogledom pri našem razumevanju prostora. Ta dva vidika našega razumevanja odražata različen odnos s pokrajino. Naša življenja živimo s pokrajino in imamo občutek, da smo del pokrajine, hkrati pa gledamo na pokrajino kot na nekaj zunanjega. Pokrajina je središče pomenov in zunanji kontekst naših dejanj.

Dualistična kakovost prostora je bila v središču geografskih konceptov kot horološka znanost, ki je poudarjala razmerja med ljudmi in njihovim okoljem. Geografov pristop se dejansko nagiba k horologiji, k neki obliki razumevanja, ki je rezultat opisa in razlage. Pokrajina je seveda prostor s številnimi vhodi; o njej ne moremo poglobljeno razmišljati samo od zunaj, temveč jo moramo dejansko »prepotovati«. Geografija pa seveda ne misli samo z nogami.

Za razumevanje pokrajine moramo imeti torej dostop tako do objektivne kot do subjektivne stvarnosti. Proučevanje pokrajin je zato zasnovano na podlagi analiz, ki leže med tako imenovanim »centralističnim in decentralističnim pristopom« (Entrikin, 1991). Relativno subjektivni vidik je »središčni« vidik, v katerem smo del prostora in časa, relativno objektivni vidik pa je decentraliziran vidik, v katerem poskušamo preseči tukaj in sedaj. Z decentraliziranega vidika postane pokrajina splošno razmerje in s tem izgubi velik del njene pomembnosti za človeka, pri centraliziranemu vidiku pa ima pokrajina pomen samo v povezavi z individualnimi ali skupinskimi cilji. Razhajanja med decentraliziranim univerzalizmom in centraliziranim partikularizmom se kažejo najpogosteje v epistemoloških razpravah glede geografskih individualnosti. Soočeni smo z različnimi razmerji med partikularnimi in univerzalnimi razpravami in med subjektivnimi in objektivnimi perspektivami.

V geografiji ponuja opisen način eno izmed možnosti za določeno obliko povezovanja partikularno-univerzalnega ter subjektivno-objektivnega pristopa. Opis je, razen zelo redkih izjem, rezultat selektivnega dela. Na nek način smo geografi prisiljeni razdrobiti vsebinsko pestro bogastvo pokrajine v posamezne, pogosto na videz samovoljne elemente, pojave, procese in kategorije, saj je drugače sploh ne bi mogli prikazati oziroma analizirati. Pri tem pa pokrajine ne členimo zgolj zaradi analitičnega pristopa oziroma spoznavanja posameznih sestavnih delov prostora, temveč predvsem zaradi opredeljevanja pomenov in razumevanja celotne pokrajine. Pokrajine se nanašajo na konceptualno zlitje prostora in izkušenj s prostorom, ki dajejo območjem zemeljskega površja »celovitost« in »individualnost«. Geografski koncept se nanaša na konkretno naravo stvarnosti, in sicer na tisto, ki jo zaznavamo. Empirične trditve ali dejstva o prostoru pa so selektivni opis stvarnosti. Geografi pa moramo pri pokrajini »videti« tudi vse tisto, kar je nevidno, kar je in kar ustvarja pokrajino.

Geografski koncept se nanaša na tri različne analitične pristope, ki pa so med seboj $\mathrm{v}$ določenih prepletenih razmerjih: empirično-teoretični pomen se nanaša na vprašanja o 
prostorskih spremembah, normativni pomen se nanaša na vrednote povezane s prostorskimi spremembami, epistemološki pomen pa na vprašanja znanstvenega značaja raziskav.

$\mathrm{Z}$ epistemološkega vidika poskušamo geografi, na eni strani opredeljevati širšo podlago znanstvene epistemologije. Utemeljevati poskušamo znanstveno razlago z iskanjem zakonov, na drugi strani pa iskati humanistični vidik stroke, ki se nanaša predvsem na proučevanja konkretnih razmerij med družbo in materialnim svetom. Ob epistemološkem problemu, da moramo vedno začeti s pokrajino, takšno kakršna je, nam tudi kompleksnost pokrajine povzroča številne težave pri spoznavanju temeljnih pojavov in procesov in njihovega natančnega in pravilnega opredeljevanja. Različni procesi in pojavi se prepletajo in ustvarjajo kompleksne oblike prostorskih sprememb (Černe, 2007).

Fenomenalizem poskuša pojasniti vso človeško vednost $\mathrm{z}$ recepcijo in interpretacijo čutnih podatkov. Paassenova opredelitev je naslednja: »Geografska znanost ima dejansko fenomenološko podlago, to pomeni, da izhaja iz geografskega zavedanja. Na eni strani geograf razvija to zavedanje in vpliva na višjo stopnjo zavesti družbe o geografiji, na drugi strani, pa je razvoj geografske znanosti odvisen od obstoja pred znanstvene in naravno geografske zavesti ....; geografi in geografija obstaja samo v družbi z geografskim občutkom« (Relph, 1976, 18). Fenomenološki temelji geografije ležijo na neposrednih izkušnjah in zavedanju, ki ga imamo o svetu v katerem živimo. »Fenomenologija pokrajine je teorija, ki razume pokrajino v smislu prostora s katerim človek biva. S fenomenološkega vidika bi lahko rekli, da nas geografija usmerja k odkrivanju pomenov, ki jih vsebuje življenje s prostorom. Pokrajina je konkretna manifestacija človekovega bivanja s prostorom, in fenomenologija poskuša zaobseči vse njene pomene. Vidal de la Blache je ta vidik opisal z besedami »zemlja, kot prizorišče na katerem se odvijajo človekove dejavnosti«. Tudi tiste pokrajine, v katerih človek ne biva, so del teh razmerij, saj je človek prepoznal, da v teh pokrajinah ni primernih pogojev za bivanje ali pa se je zavestno odločil, da v teh pokrajinah ne bo bival zaradi takšnih ali drugačnih razlogov. Ta fenomenološka podlaga za geografijo je na široko sprejeta s strani številnih geografov.

Geografski koncept je organicističen in ne atomističen. Atomizem namreč trdi, da realnost sestavljajo posamezne enostavne enote - da so posameznosti stvarnejše kot celota, ki je pravzaprav zgolj abstrakcija. Organicizem pa pravi, da je celota stvarnejša kakor deli, celota je organska, deli pa so popolnoma odvisni od nje. Zato so po svoje manj realni kot celota. »Organicistični« pristop proučuje pokrajino kot neodvisno celoto, ne pa kot serijo posameznih individualnih delov. Pokrajina »je medsebojno povezana celota«. Geografija zagovarja ontološki nazor, ki pravi, da je celota bolj realna od katerega koli dela in da deli dobijo realnost od celote, če želimo opisati celotno pokrajino. S tega vidika je potrebno obravnavati človekova razmerja do njegovega okolja kot regionalno celoto (Worster, 1994).

\section{POKRAJINA KOT PROSTOR}

Demokrit, Epikur, Lukrecij, Pitagora, Platon, Aristotel in mnogi njihovi učenci so se v vsej zgodovini tako ali drugače borili s pomenom prostora. V zahodni civilizaciji je prva resnična celovita opredelitev prostora, znana Aristotelova teorija o kraju, ki je verjetno prvi 
primer pristopa h konceptualizaciji prostora: »Vsako telo zaseda določen kraj, in telo ne more obstajati v kolikor njegov kraj ne obstaja«. Odgovori na vprašanje, ali je prostor resnična entiteta, ali zgolj abstraktna zamisel, ali popolnoma prazen, segajo od Isaaca Newtona, ki je v 17. stol. trdil, da je prostor resničen, prek Ernsta Macha, ki je v 19. stol. zaključil, da ni, Einsteina, ki je v 20. stol. spojil prostor in čas, do domnev, da naj bi bil prostor prežet s tako imenovanimi kvantnimi polji in morda tudi z razpršeno enakomerno energijo, imenovano kozmološka konstanta (Greene, 2005).

Različni koncepti o prostoru zelo pogosto temeljijo na prizadevanjih po namenu in redu $\mathrm{v}$ prostoru kot celoti. Iskanje reda, ki se je tradicionalno zakoreninilo v zahodni znanosti od renesanse naprej, se je samo po sebi spremenilo od razporejanja in kategoriziranja stvari in razmerij med stvarmi k načelom, ki ustvarjajo red. Značaj pokrajine in njena odvisnost od vode sta bili pri Sumercih prežeti s specifičnim konceptom urejenosti (reda), in neločljivo povezani z obstojem, tako da sta pojma »ustvariti« in »postaviti v red« sinonima. »Načelo polnosti«, ki vsebuje implicitno spoznanje o veliki raznolikosti življenja in njegovih težnjah po mnogovrstnosti, zasledimo že pri Platonu. Pomen narave in naravnega okolja v zgodovini grške civilizacije je poudaril Scully (Glacken, 1967). »Formalna elementa grških svetišč sta posebna sveta pokrajina $v$ katero je postavljeno svetišče, in zgradbe, ki so nameščene $v$ to pokrajino. Pokrajina in svetišča skupaj tvorita celoto. Svetišča so Grki načrtovali na jasnih horizontih med nebom in morjem ter določali njihovo velikost glede na njihov položaj na ravnini ali hribu ali širšemu platoju akropole. Svetišče so si predstavljali v razmerju do hribov in morja ter nebesnega oboka...« (Scully, 1997, 12).

Grki so delno podedovali delno pa razvili posebno »oko« za določene nenavadne specifične kombinacije značilnosti pokrajine, ki se izražajo v slikoviti celovitosti. Razloge za to bi lahko iskali v tem, da zemlja ni bila slika, marveč resnična sila, ki je fizično utelešala sile, ki vladajo svetu.

Zgodnji jonski koncepti o »physis« so kombinirali fizične s človeškimi in božjimi komponentami. Klasičen grški pojem kosmosa, ki sta ga uporabljala Platon in Aristotel, in rimska natura, sta ohranila idejo o stvarnosti kot harmonični, vse obsegajoči celoti. Grki so v klasični dobi zagovarjali vseobsežno celovito strukturo stvarnosti: kozmos. Ta pojem je v originalu pomenil »red«. Prepričanje, da sta tako bistvo stvarnosti in naše znanje končno sestavljeni iz oblik (form) pomeni, da se oblika, ki pripada bistvu stvarnosti, kaže v nekem določenem redu. Z raziskovanjem stvarnosti kot harmoničnega videza, je grški pogled odkrival enkratno estetsko kakovost, ki se je kazala tako v arhitekturi, kot v kiparstvu in filozofiji (Dupre, 1993, 9, 10).

Grki so zagovarjali istočasno prisotnost enotnosti in mnogoterosti, reda in kaosa, harmonije in konfliktov. Ta nasprotujoča načela so poskušali ohranjali v nekem ravnotežju. Permenid je poskušal stvarnost reducirati na enotnost brez mnogoterosti. Kasneje so iskali bistvo stvarnosti v kompleksnosti harmoničnih oblik. Večja, ko je formalna kakovost stvari, v večji meri stvar zasluži, da jo imenujemo stvarnost. Od tod tudi presenetljiv odnos do najvišje stvarnosti kot lepote, to je popolne forme (oblike). Oblika deluje torej kot načelo, ki urejuje (usklajuje) neskladje sil nasprotij (navzkrižij) in nereda. Za zahodne filozofe je veljalo prepričanje, da ničesar ne more v celoti biti stvarno, ne da bi bilo v stanju harmonije (Dupre, 1993, 18). 


\section{POKRAJINA KOT KRAJ}

Geografija mora prepoznavati »genius loci«, saj je njen predmet proučevanje pokrajin, regij, krajev in območij, ki imajo določen pomen.

Genius loci je rimski koncept. Glede na antično rimsko verovanje ima vsako »neodvisno« bitje njegov genius, njegovega duha, ki ga varuje. Ta duh daje življenje ljudem in krajem, jih spremlja od njihovega rojstva do smrti in determinira njihov značaj oziroma bistvo. Celo bogovi imajo njihove genius, dejstvo, ki ponazarja temeljni značaj koncepta genius loci. Genuis označuje torej kaj stvar je, ali kaj želi biti. Antični človek je izkušal oziroma doživljal njegovo okolje kot, da je sestavljeno iz določenih značajev. Spoznal je, da je duh določenega kraja izrednega eksistencialnega pomena. Za antičnega človeka je bilo življenjskega pomena njegovo soočenje $z$ duhom kraja, saj poteka njegovo življenje v tem kraju. V preteklosti je bilo preživetje odvisno od »dobrega« razmerja do kraja v fizičnem in psihičnem smislu (NorbergSchulz, 1984, 18).

Kraji imajo lahko »dušo« ali »osebnost«, toda samo človek ima lahko občutek o kraju (Tuan, 1974, 234). Ljudje demonstrirajo svoj občutek o kraju takrat, ko usmerjajo njihove moralne in estetske razsodnosti v kraje in lokacije. Pri tem ima občutek dva pomena. En pomen je vizualen ali estetski. Oko je potrebno naučiti zato, da lahko odkriva lepoto tam, kjer obstaja; na drugi strani pa je potrebno ustvarjati lepe kraje, da se dopadejo očem. Z določenega omejenega vidika so kraji lokacije, ki imajo vizualne učinke. Na ravnini so osamljeni vrhovi in prsti kraji; na kraških območjih so kraška polja kraji. Poleg tega poznamo svet ne samo s pomočjo vida marveč tudi s pomočjo drugih čutil: sluha, vonja, okusa in tipa. Ti občutki, za razliko od vida, zahtevajo bližji stik in dolgo druženje z okoljem. Možno je ceniti vidne kakovosti mesta na popoldanskem ogledu mesta, če pa želimo spoznati vonjave in glasove mesta, teksturo njegovih pločnikov in zidov, pa moramo biti v mestu dalj časa.

Teorijo o »avri« govori o tem, da imajo predmeti avro, ki je rezultat njihove jasne lokacije v prostoru in času. Predmeti so točno določeni v prostoru in času - to pomeni, da so enkratni in jih ne moremo reproducirati. Avre predmetov najpogosteje sprejemamo v stanju koncentracije, medtem ko teži grajeno okolje k temu, da ga dojemamo v stanju razpršenosti. Zato je Benjamin proučeval zgradbo mesta kot besedila preko pomenov in vrednot, ki so zakodirana v grajenem okolju (Thinking Space, 2000).

James je zapisal, da geografijo zanima povezanost stvari, ki dajejo določen značaj določenim krajem, Sauer govori o geografskih dejstvih, ki so dejstva o krajih in njihova povezanost je temelj koncepta pokrajine, Hartshorne je imel integracijo, s katero se geografija ukvarja pri analizi, za tisti pojav, ki se spreminja od kraja do kraja, Lukerman pa je bil prepričan, da je geografija znanje o svetu, ki obstaja v krajih. Ad hok komite za geografske znanosti je zapisal, da »moderna geografska znanost utemeljuje njen predmet iz človekovih občutkov o kraju in njegove radovednosti o prostorskih značilnostih (atributih) zemeljskega površja in atmosferskega ovoja zemlje (Relph, 1976).

Analiza koncepta o kraju, ki ga je opredelil Lukermann (1964) kaže šest pomembnih komponent:

- $\quad$ idejo o lokaciji, ki jo lahko opišemo v smislu notranjih značilnosti (karakteristik) položaja (lege) in zunanje povezanosti z ostalimi lokacijami; 
- $\quad$ kraji vsebujejo integracijo elementov narave in kulture: vsak kraj ima svoj red, njegov poseben »ensemble«, ki ga ločuje od drugega kraja; vsak kraj je enkratna entiteta;

- $\quad$ čeprav je vsak kraj enkraten, so kraji med seboj povezani s sistemom prostorskih interakcij in gibanjem;

- $\quad$ kraji so lokalizirani - so del večjih območij in so žarišča v sistemu lokacij;

- $\quad$ kraji se pojavljajo ali nastajajo; kraji imajo jasno zgodovinsko komponento;

- $\quad$ kraji imajo pomen; označeni (opisani) so z razmišljanji človeka.

May pa se zavzema za bolj analitični pristop, v katerem poudarja, da se pojem kraja z geografskega vidika nanaša na:

- celotno površino zemlje (ideja o zemlji kot kraju bivanja človeka);

- $\quad$ prostorsko enoto (mesto ali naselje, dežela, regija);

- določen in specifičen del prostora in tisto, kar lahko ta prostor zaseda (kraj bivanja);

- $\quad$ »lokacijo« v smislu točno določenega položaja (kraj je sestavljen iz številnih stvari, ki so lahko specifično locirane) (Relph, 1976).

\section{KONCEPT SPECIFIČNOSTI, ENKRATNOSTI IN INDIVIDUALNOSTI}

Specifičnost pokrajine je povezana z objektivno-subjektivno polarnostjo in s koncepti o enkratnosti (originalnosti), konkretnosti in idiografičnosti. Epistemološke zahteve, ki se nanašajo na raziskave posameznih primerov so bile velikokrat pomešane $\mathrm{z}$ ontološkimi vsebinami povezanimi z enkratnostjo. Ko obravnavamo prostor $\mathrm{v}$ njegovem najbolj objektivnem smislu lokacije, je vsak prostor različen, preprosto zaradi njegove relativne lokacije. Noben drug prostor nima take, enkratne lokacije, in v tem smislu je vsak prostora enkraten. V drugem primeru je prostor specifičen zato, ker ima vsak kraj določen pomen. Prostor postane specifičen šele takrat, ko mu ljudje pripišejo določen pomen, saj prostor ni specifičen zaradi njegovih naravnih značilnosti, marveč predvsem zaradi tega, ker mu ljudje pripisujemo določene pomene. Leta 1937 so v poročilu Komiteja geografskega združenja z naslovom »Klasifikacija regij na svetu poskušali opredeliti dva tipa regij: »generične regije« naj bi bile rezultat sistematične regionalne geografije in so neka oblika prostorske klasifikacije; »specifične regije« pa naj bi se nanašale ne relativno različen značaj določenih krajev oziroma na enkratna območja na zemeljskem površju, ki imajo določeno geografsko individualnost (Entrikin, 1991). V neo-Kantovski argumentaciji horologije, ki so jo zastopali Alfred Hettner, Richard Hartshorne in P. Vidal de la Blache, je bila regija razumljena kot miselni (mentalni) konstrukt, zato so se vsebine enkratnosti nanašale na cilje snovanja konceptov, ne pa na značilnosti »stvarnih« regij na svetu.

V geografiji je dolgo časa potekala razprava (v večjem delu 19. stol.) med zagovorniki »idiografskih« in »nomotetičnih« pogledov. Oba sta načina abstrakcije, s katero iščemo zasnovo racionalnega reda iz neskončne stvarnosti. Večina teh razprav se nanaša na konceptualizacijo geografskih pojavov, v manjši meri pa na generiranje predpostavk o pravilnostih ali prostorskih vzorcih. Geografi smo v večji meri zainteresirani za značaj pojavov, za procese, 
ki jih ustvarjajo in njihove učinke, kot pa za to, ali ti pojavi ustvarjajo pravilnosti ali ne. Harvey je zapisal, da daje dialektično mišljenje večjo težo razumevanju procesov, tokov, spremembam in razmerjem kot pa analizi elementov, stvari, struktur in organiziranih sistemov. Pri tem obstaja globoko ontološko načelo, » .... da elementi, stvari, strukture in sistemi ne obstajajo izven ali pred procesi, zaradi katerih so te stvari, strukture in sistemi nastali, nastajajo, se ohranjajo ali propadajo. Z epistemološkega vidika je predpostavka o procesu raziskovanja in proučevanja najpogosteje obrnjena: do razumevanja procesov pridemo $\mathrm{z}$ gledanjem značilnosti tistega, kar se nam kaže .... (Harvey, 1997, 49).

Raziskave o specifičnosti pokrajine je bistvena značilnost horologije, ki pomeni neke vrste začetka razvoja nomotetične znanosti. Horologija ima dve skrajnosti, objektivnost fizikalne znanosti in subjektivne presoje umetniških stvaritev. Raziskave o posebnostih (izjemnostih) lahko uporabljamo za raziskave o specifičnosti pokrajin. Razlage o prostorskem razlikovanju na zemeljskem površju zahtevajo ravnotežje med vzročnimi analizami in narativnimi sintezami. Zahteve po znanstveni legitimnosti v geografiji so prispevale $\mathrm{k}$ opustitvi tega horološkega cilja in usmeritvi k označevanju pokrajin v smislu nomotetične generalizacije ali stvarnih razmer. Nomotetični pristop ponuja razumevanje pokrajin kot tipov, medtem ko so bile stvarne razmere povezane z naivnim realizmom, pri katerem je v ospredju trditev, da lahko opišemo pokrajine tako »kot v resnici so«.

Pokrajinam pripisujemo tudi določeno individualnost, neke vrste »ne-deljivost«, vendar ne samo zato, ker je enkratna $\mathrm{v}$ najbolj splošnem pomenu besede. Individualnost je značilnost pokrajina zato, ker so njene lastnosti in značilnosti skladne in nedeljive, kar je odlika enkratnosti pokrajine. Individualnost pa ni opredeljena na podlagi vseh značilnosti in lastnosti pokrajine, saj obstaja samo na podlagi tistih specifičnih značilnosti in lastnosti, ki so nujne, saj so to tiste, ki so temeljnega pomena za skladnost in nedeljivost. Vsaka pokrajina je enkratna zato ji moramo posvetiti veliko pozornosti, če jo želimo najprej opisali, nato pa še razumeti. Vsaka pokrajina ima enkraten značaj, ki ga moramo spoznati in razumeti ter upoštevati in spoštovati, preden se bomo odločili, da ga bomo spremenili. Naš uspeh pri spreminjanju pokrajin lahko merimo v smislu naše sposobnosti, da uravnavamo in prilagajamo naše potrebe v skladu z značilnostmi strukture pokrajine. Pri tem pa gre za temeljno vprašanje, kako daleč se lahko oziroma se moramo prilagajati prostoru? Oziroma kako daleč lahko ali bi moral iti, ko vstopamo v prostor in njegov red za naše lastne potrebe?

\section{KONCEPT CELOVITOSTI, HARMONIČNOSTI IN URAVNOTEŽENOSTI}

Namen holistične (celostne) raziskave je združiti različne perspektive v enovito vedenje. Geografska sinteza vključuje načine videnja in vedenja, ki bi ga lahko opisali kot poskus »videnja stvari skupaj«. Holistični vidik obravnava pokrajino kot enotno, nedeljivo celoto na podlagi upoštevanja kompleksne celote prostora in kakovosti medsebojne funkcionalne povezanosti. Členitev (razbitje) pokrajine na njene sestavne dele ne more voditi v razumevanje celote. Preseči moramo zgolj neke vrste »taksonomije« oziroma klasifikacije, razvrščanje in poimenovanje ter opisovanja pojavov in procesov v prostoru. Značilnosti pokrajine nastajajo iz medsebojnih zvez in učinkov. 
V geografiji je holistična kakovost prostora razumljena kot značilnost našega videnja sveta. Pri tem pa obstaja velika težava predvsem pri opredeljevanju meril na podlagi katerih pripisujemo pomene tej celoti. Geografija opisuje pokrajino z vidika sinteze heterogenih pojavov, saj poskuša »videti stvari skupaj«. Ravno pri narativni geografski razlagi je pojavom dan pomen na podlagi njihovega položaja oziroma razmerja s celoto. Geografi na veliko razpravljamo o tej celoti. Koncept »ena stvar za drugo « za razliko od »ena stvar zaradi druge«. Pokrajina je s tega vidika razumljena kot enota raznolikih, vendar medsebojno povezanih delov. Njen razvoj se kaže kot funkcija harmonije njenih sestavnih delov. Ideja o prostorski harmoniji ali prostorskem ravnotežju se nanaša na trditev, da pokrajina povezuje njene sestavne dele v koherentno »integrirano« celoto. Narativna geografska razlaga na nek način kombinira horološke poskuse povezovanja objektivnih »dejstev« o prostoru v vseobsežno celoto, s humanističnimi poskusi povezovanja dejavnikov (akterjev) z njihovim okoljem. Na nek način poskuša povezati skupaj dejavnike in strukture, namene in okoliščine, splošnost in posameznost in istočasno iskati razlage za vzročnost.

Koncept Zemlje kot urejene harmonične celote, ki je primerna za bivanje človeka oziroma za vse oblike življenja, je zelo star. Skrajne korenine moramo iskati verjetno v prejšnjih verovanjih o neposrednem poseganju bogov v človekove zadeve ali v personifikaciji naravnih procesov pri imenovanju božanstev ali v mitih o materi zemlji. Grški koncept o »oikoumeni« je bil del grške tradicije; v antičnem obdobju je beseda imela vsaj šest pomenov, toda najbolj razširjen je bil pomen »naseljenega (poseljenega) sveta«: svet, ki je obljuden in sposoben vzdrževati življenje. Koncept »oikoumene« je temeljil na spoznanju, da ljudje žive v različnih okoljih, včasih podobnih, najpogosteje pa različnih. Ne samo, da je lepota v kozmičnem redu, marveč je tudi sreča in veselje $\mathrm{v}$ lepoti zemlje $-\mathrm{v}$ grški pokrajini z menjavanjem kopnega in morja, njenimi številnimi otoki, njenimi kontrasti med očarljivimi obalami in strmimi gorami in surovimi klifi in raznolikost rastlin in živali v teh pokrajinah. Italijani so bili med Evropejci verjetno prvi narod, ki je v podobi pokrajine iskal in ugotavljal lepoto pokrajine in hkrati užival v njeni lepoti. Sposobnost uživanja lepote pokrajine pa je seveda rezultat dolgotrajnih, zapletenih procesov.

Koncepti ravnotežja in harmonije v naravi so bili zaobseženi v zgodnjih ekoloških teorijah, čeprav je bila ideja o temeljnih težnjah k ravnotežju v naravi s strani znanstvenikov kasneje zavrnjena. Niti narava niti družba nista stabilni entiteti. Sedaj ne vemo samo to, da so spremembe resnične, marveč tudi, da so spremembe zelo različne. Nobene spremembe ne moremo vzeti kot normativ, prav tako kot ne moremo sprejeti kot normativ določenih stanj ravnotežja. Izrazi ravnotežje ali harmonija govorijo v bistvu o obstoju zamotanih razmerij in zapletenem prilagajanju njenih sestavnih delov. Harmonija ne izhaja iz natančne skladnosti, marveč iz določenega obsega različnosti. Prostor je enota, organizem, ki potrebuje (zahteva) ravnotežje, in sicer tisto ravnotežje, ki je zasnovano na različnosti. Mumford je opredelil »organsko enoto kot integracijo, harmonijo in ravnotežje, ki idelano, združuje različne sestavine življenja in daje človekovim izkušnjam pomen in namen« (Entrikin, 1991, 80). Ravnotežje in različnost sta dejansko dva koncepta, ki nam pomagata opredeliti prostor. Dejstvo o raznolikosti je Mumford opredeljeval kot srečevanje, prepletanje in zlivanje različnih tipov, »nebeškost« in medsebojno menjavo različnih okolij, ki so bistvenega pomena za usklajeno regionalno življenje«. Mumford je v regionalizaciji videl instrument za doseganje naboljšega 
možnega življenja, in sicer s ponovnim povezovanjem družbe in njenega naravnega okolja. Ravnotežje in raznolikost sta bila temeljni sestavini zdravega regionalzma, saj bi brez njiju regije postale preprosti prostorski izrazi različnih kultur.

\section{POKRAJINA}

Pokrajina je geografsko videnje prostora, hkrati pa označuje enovit koncept geografije, ki se nanaša v prvi vrsti na posebno združevanje dejstev (Černe, 2005). Pri pokrajini gre za razumevanje, spoznavanje prostora v vsej njeni neposrednosti. Pokrajine nam pomagajo pri snovanju prostora, s katerim živimo družbeno, kulturno in osebno življenje. Pokrajina je vselej prostorsko konkretna, je geografski način predstavljanja, strukturiranja in simboliziranja prostora, tako po svoji enkratnosti kot celota, kot po svojstvenih pojavih in procesih. Pokrajina pa ni samo način videnja prostora, marveč eden izmed možnih načinov predstavitve, neka oblika odtisov v prostoru. Pokrajina ni samo podoba, ki se nanašajo na neko določeno stvarnost, marveč razmerja, ki ustvarjajo in predpostavljajo pokrajino samo po sebi. Hkrati pa geografija konceptualizira prostor kot kodirano besedilo, ki ga lahko prepoznajo tisti, ki razumejo prostor kot celovito pokrajino.

\section{Koncept razumevanja pokrajine*}

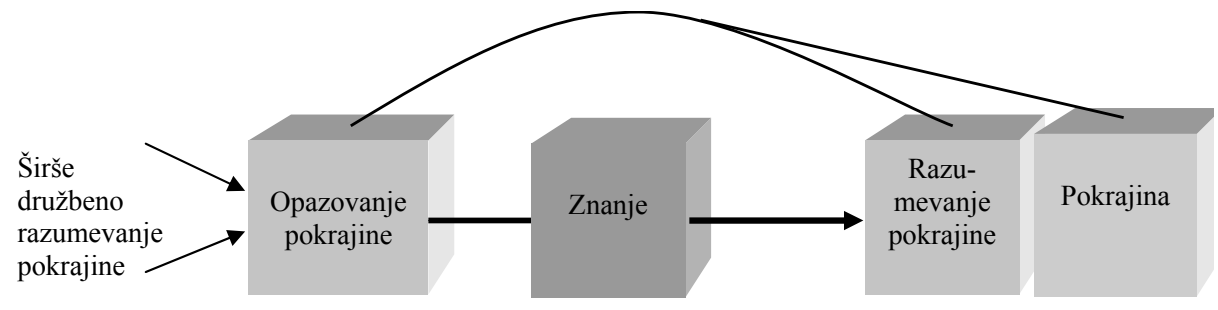

*prirejeno po Castree, 2005

Geografi prostora ne opredeljujemo kot abstraktna razmerja, saj ima neodvisno vsebino, to pa je pokrajina. To pomeni poudarjanje materialnega in človekovega pričevanja $\mathrm{v}$ pokrajini, povezovanje in součinkovanje fizičnih in družbenih pojavov. Pokrajina se kaže kot neka oblika materializacije spreminjanja razmerij med naravo in družbo, je rezultat materialnega in človekovega spreminjanja prostora. Geografi poskušamo razumeti, kako je človek spreminjal njegovo materialno okolje. Zato se geografska interpretacija pokrajine nanaša na materializacijo pokrajine kot objekta empiričnega raziskovanja. Geografske interpretacije so sestavni element v kompleksnem, posameznem in družbenem procesu, kjer ljudje neprestano spreminjamo prostor v območja in področja pomenov ter življenjskih izkušenj. Ta območja in področja so geografsko, družbeno in zgodovinsko specifična. Pokrajine so medij in rezultat naravnih in družbenih procesov, in zato imajo, v pravem pomenu besede, integralno vlogo v razvoju. Geografi pokrajine ne spoznavamo s ptičje perspektive, marveč z izločanjem in intenzivnim raziskovanjem določenih specifičnih pojavov, procesov in struktur, z njihovim razumevanjem in raziskovanjem v kontekstu prostora kot takega oziroma nastajanja prostor- 
skih struktur v določenih časovnih obdobjih. Geografi poskušamo razumeti pokrajino v vsej njeni celoti, z vsemi njenimi podobami, strukturami, funkcijami in zgodovinami. Skrivnost pokrajine je v njeni celovitosti. Prvine posameznih pokrajin se prepletajo in so velikokrat v medsebojnih nasprotjih - na nek način se dopolnjujejo, niso pa med seboj popolnoma zlite. Pojavi, ki tvorijo pokrajino niso preprosto razporejeni in urejeni, marveč obstajajo skupaj $\mathrm{v}$ pokrajini, so povezani in v medsebojni odvisnosti. Tvorijo stvarnost kot celoto, ki pa ni izražena $\mathrm{z}$ upoštevanjem posameznih medsebojno ločenih sestavnih delov, saj ima pokrajina svojo obliko, strukturo in funkcijo in zaradi tega položaj v prostorskem sistemu in je predmet sprememb in razvoja.

Pokrajina ni samo prostorski parameter in fizično okolje, kjer se odvijajo pojavi in procesi oziroma razmerja med temi pojavi in procesi, marveč šele vsi ti dejavniki skupaj tvorijo celoto teh razmerij. Družba je s prostorom v stalnem, vendar vedno spreminjajočem se razmerju. Razumeti pokrajino pomeni razumeti geografsko predstavitev prostora, ne kot "podobe«, marveč kot neprestano spreminjanje njenih pomenov. Pokrajine so vedno v neprestanem procesu nastajanja, zato na njih nikoli ne smemo gledati kot na končni izdelek.

Geografi govorimo o alpski, gozdni, agrarni, kraški pokrajini. Kaj imajo vse te pokrajine skupno? Če se jih ogledamo, ne bomo našli nič, kar je skupnega vsem, temveč le podobnosti in povezave. Vidimo zapleteno mrežo podobnosti, ki se delno pokriva in križa - včasih povsem, včasih v podrobnostih. Geografi se zavedamo, da imajo različne pokrajine tudi določene skupne lastnosti, na podlagi katerih bi lahko poskušali opredeliti splošen pojem pokrajine. Hkrati pa se tudi zavedamo, da je splošni pojem prav gotovo vsebinsko revnejši od katerekoli konkretne pokrajine. Verjetno je opredeljevanje pokrajine naloga, ki je pravzaprav ni mogoče končati, saj nobena končna opredelitev splošnega pojma pokrajine ne more v celoti zaobseči vseh lastnosti določene pokrajine.

\section{POMENI POKRAJIN}

Geografi raziskujemo tiste pomene, ki jih družba pripisuje prostoru ter tiste človekove vrednote in cilje, ki prispevajo k aktivnemu nastajanju in spreminjanju pokrajin. Humanist Relph (1976) poudarja enkratno kakovost človeških bitij, in sicer kot tistih dejavnikov, ki imajo določene namene pri ustvarjanju razmerij s prostorom. Različnih pomenov pokrajine ne moremo poznati, če teh pomenov ne spoznavamo na določenem konkretnem primeru ali z definicijo oziroma opisom tega pomena. Pomene, ki jih pripisujemo pokrajini se širijo od osebnega, relativno subjektivnega razumevanja prostora, ki je povezano z osebnimi izkušnjami, do relativno objektivnih mnenj o prostoru. Pomen določenega prostora ni nekaj kar bi lahko našli v prostoru, marveč ga moramo razumeti v razmerju do subjekta. Zato prostor ne predstavlja samo podlage za organiziranje človekovih dejavnosti, marveč je proces v neprestani dinamiki človekovega spreminjanja naših razmerij s svetom (Tuan, 1974). Prostor je tudi del identitete posameznikov in skupin, del tega, kako vidimo sami sebe v razmerju do drugih in kakšen pomen dajemo redu pri naših izkušnjah s prostorom. V ospredju proučevanja je pomen posameznika, katerega dejanja niso oblikovana samo na podlagi materialnih potreb, marveč tudi na podlagi geografskih predstav, ki vključujejo moralne in etične ideale. 
Humanistična geografija je osredotočena na odkrivanje pomenov, vrednot in razlag in pri tem poudarja pomen izkušenj. Humanistični geograf raziskuje človeško naravo krajev, saj je človek primarni ustvarjalec krajev. Pokrajine neprestano spreminjamo, tudi na ta način, da dajemo materialno obliko našim namišljenim svetovom. Pokrajina je dinamična sestavina, ki neprestano nastaja in se oziroma jo spreminjamo na različnih ravneh. Pokrajina je rezultat neprestanega prepletanje naravnih in družbenih procesov. Izhodišče humanistične geografije je človek, katerega moč leži predvsem v jeziku, v moči ustvarjanja pomenov in sposobnostih komuniciranja in sodelovanja $\mathrm{z}$ drugimi. Specifičnost kraja je bila povezana $\mathrm{z}$ enkratnimi izkušnjami o kraju in pomenom, ki jih pripisujemo tem izkušnjam. Enkratnost na ta način postane predvsem funkcija kakovosti izkušnje, ne pa toliko opis kraja.

Humanisti iščejo razumevanje izkušenj s pomočjo »domačinov《. Pomembnost kraja je s humanističnega vidika neločljiv del zavedanja tistih, ki živijo s tem krajem. Specifičnost krajev je torej funkcija enkratne izkušnje, ki jo imajo posamezniki in skupine, ki so povezane s krajem. Specifičnost je opisana v smislu enkratnosti, kakor tudi v smislu zlitja kraja in izkušenj v praktičnem vedenju. Argument enkratnosti je povezan s prepričanjem, da je prostor pomemben zato, ker se družbeni procesi odvijajo v krajih, kraji pa se med seboj razlikujejo (Approaches ..., 2006).

Pokrajine so bile vedno strukturirane in imele določeno identiteto, ki jim jo je pripisoval človek na podlagi namenov in izkušenj s pokrajinami, in so vedno izražale kulturna (lahko tudi ne kulturna) razmerja in odnose ter verovanja in predstavljala kontekst za temeljne in vsakdanje potrebe in izkušnje ljudi, ki so živeli s pokrajinami.

Pokrajine združujejo človeški in naravni red in so pomembna središča naših neposrednih izkušenj in doživljajev sveta. Pokrajine niso abstrakcije ali koncepti, marveč neposredno doživeti pojavi sveta, ki ga živimo in so zato polni različnih pomenov. So pomemben vir individualne in skupne identitete in so pogosto globoka središča človekovih izkušenj do katerih imajo ljudje globoke čustvene in psihološke povezave.

Pomeni pokrajin niso samo posledica njenih fizičnih značilnosti marveč in predvsem tudi dejstva, da je pokrajina temelj bivanja in samozavedanja. Pri geografskem konceptu Evrope oziroma geografskemu pristopu k Evropi se Brague opira na tri pomene geografskega pristopa: na etimologijo, na pomen prostora, kot so ga razumeli Grki in na celoten prostor, ki mu lahko pripadamo (Brague, 2003, 11).

Geografi proučujemo pomen pokrajine tudi pri vprašanjih identitete posameznika in skupine, saj ima prostor pomembno vlogo pri nastajanju identitete posameznika in identitete skupnosti. Pokrajine notranje povežejo naša razmerja s prostorom, saj združujejo skupaj fizična, družbena simbolna in psihološka razmerja ter na ta način nudijo neko vrsto identitete.

Za Lyncha je identiteta kraja tisto, kar omogoča njegovo individualnost ali različnost od drugih krajev in služi kot podlaga za njegovo prepoznavanje kot ločeno entiteto. Ian Narin $(1965,78)$ pa je zapisal: ».....obstaja toliko različnih identitet, kolikor je ljudi«, saj je identiteta izkušnja, oko, spomin in intencija opazovalca prav toliko, kolikor jo je v fizični pojavnosti mesta ali pokrajine. Ne glede na to, koliko lahko posameznik pripisuje zavestno ali nezavedno identiteto določenemu kraju, je ta identiteta kljub temu kombinacija inter-subjektivnosti, ki tvori skupno identiteto (Lynch, 1960, 6). 
Identiteto je razumeti torej kot sestavni del identitete kraja, kot obliko in ravni zunanjosti in notranjosti ali identitete s krajem, kot povezave med posameznimi, skupinami in masovnimi podobami krajev, in kot načine na podlagi katerih te identitete nastajajo, se ohranjajo in spreminjajo. Obstaja tesna povezava med krajem, spominom in identiteto: »Kraj je prostor, ki ima zgodovinski pomen, kjer so se nekatere stvari zgodile, ki se jih sedaj spominjamo in tvorijo kontinuiteto in identiteto skozi generacije. Kraj je prostor, kjer so bile izgovorjene pomembne besede, ki so ustanovile identiteto, opredelile namestitev in predvidele usodo. Kraj je prostor kjer so bile izmenjane zaobljube, dane obljube in postavljene zahteve« (Harvey, 1997, 26).

Identiteta je opredeljena delno z nameni in izkušnjami opazovalca. To govori v prid geografskemu idealizmu, poskusom doživljanja vseh kakovosti in pomenov kraja na tak način kot jih doživljajo ljudje, ki žive v tem kraju in tudi v smislu funkcij, estetike ali ostalih kakovosti, ki jih ne prepoznavajo lastni prebivalci.

Geografsko opisovanje pokrajin je ne nazadnje povezano tudi s tem, kako jo doživljamo. »Joseph Addison je v Eseju o užitkih domišljije pisal o čudoviti spokojnosti in presunjenosti, ki ju je čutil ob pogledu na brezmejna polja, širno neobdelano puščavo, velikanske gmote gora, visoke pečine in brezna ter obsežne vodne površine. Hildebrand Jacob je v eseju Kako veličastno privzdigne duha naštel kraje, ki najpogosteje prebujajo to cenjeno čustvo: oceane, bodisi spokojne ali razburkane, zahajajoče sonce, prepade, kraške jame in švicarske gore (de Botton, 173). Ruskin pri »slikanju z besedami« ne opisuje le videza krajev (trava je bila zelena, prst sivo rjava), temveč hkrati s psihološkim besednjakom razčlenjuje njihov vpliv na nas (trava je bila radoživa, prst plaha). Pokrajina se nam ne zdi lepa le zaradi estetskih meril - zaradi skladnosti barv - ampak tudi zaradi psiholoških meril, saj lahko uteleša neko za nas pomembno vrednoto ali razpoloženje. Ruskin je v Alpah opisal bore in skale s temi besedami: »Nikoli ne morem dolgo stati pod alpskim previsom, ne da bi začutil strahospoštovanje; ogledujem si bore kako rastejo na nedostopnih pečinah in nevarnih policah orjaške stene, v molčeči množici, vsak kot senca tistega poleg sebe - pokončni so, trdni, ne vedo drug za drugega. Ne moreš jih doseči, ne moreš jih poklicati - ta drevesa še nikoli niso slišala človeškega glasu; daleč od vseh glasov so, samo veter brije okoli njih. Še nobena noga ni stopila na iglice pod njimi. Nelagodno stojijo, vendar s tako železno voljo, da je ob njih celo skala videti skrvinčena in razpokana - krhka, šibka in nestanovitna v primerjavi z mračno energijo vzvišenega bivanja in monotonostjo uročenega ponosa« (de Botton, 240). Albert Cumas $(1959,70)$ je pisal o njegovi izkušnji o pogledu na Firence iz parka Boboli. »Miljoni oči, vem, so gledali to podobo, a za mene je bil še vedno prvi nasmeh neba. Postavil me je izven sebe v najbolj globokem smislu besede«. Gre za »topofilijo«, srečanje s krajem, ki je izredno oseben in ima globok pomen« (de Botton, 240).

$\mathrm{Z}$ vidika Bachelardove poetike prostora bi lahko zapisali, da pokrajino doživljamo $\mathrm{v}$ njeni stvarnosti in njeni virtualnosti, in tudi s pomočjo misli in sanj, saj so v pokrajini skriti tudi spomini. Pokrajina je temeljnega pomena za povezanost sedanjosti s preteklostjo in hkrati tudi tisto izhodišče, ki ga sedanjost postavlja za prihodnost. V pokrajini so istočasno prisotni preteklost, sedanjost in prihodnost. S pokrajino se ohranja povezava s preteklostjo in načrtuje prihodnost. Pokrajina je prežeta oziroma se napaja s tistim, kar se je že dogajalo z njo v preteklosti in na ta način ohranja spomin preteklosti« (Bachelard, 2001, 33). V pokrajini 
posredno prepoznavamo veliko tistega, kar je že minilo. Cilj kakršne koli razlage preteklosti je vsekakor tudi v razumevanju sedanjosti. Pokrajina na nek način ohranja spomine preteklosti, povezuje preteklost in sedanjost, čas in prostor, naravo in civilizacije, posameznika s človeštvom, in sicer znotraj prostorske konkretnosti.

\section{Literatura}

Approaches to Human Geography. 2006. Ed. Stuart Aitken, Gill Valentine, SAGE Publication, London.

Bachelard, G. 2001. Poetika prostora. Prevedla: Tanja Lesničar-Pučko, Študentska založba, zbirka Koda, Ljubljana.

Brague, R. 2003. Evropa, rimska pot. Mohorjeva družba, Celje.

Castree, N. 2005. Nature. Routledge, Oxon.

Černe, A. 2005. Pandorina skrinjica - geografski pogledi na prostorske analize v planiranju. Dela 23, Oddelek za geografijo, Filozofska fakulteta, Ljubljana, str. 235 - 243.

Černe, A. 2007.Urbano-kompleksnost, raznolikost, spremenljivost, stalnostinindividualnost. O urbanizmu. Kaj se dogaja s sodobnim mestom? Ured. Ilka Čerpes in Miha Dešman, Založba Krtina, Knjižna Zbirka Krt, str. 95-114, Ljubljana.

de Botton, A. 2001. Kako ti Proust lahko spremeni življenje. VeleNovak, Ljubljana.

Dupre, L. 1993. Passage to Modernity. An Essay in the Hermeneutics of Nature and Culture. Yale University Press, New Haven.

Entrikin, J. N. 1991. The Betweenness of Place. Towards a Geography of Modernity. The John Hopkins University Press, Baltimore.

Glacken, C. J. 1967. Traces on the Rhodian Shore. Nature and Culture in Western Thought from Ancient Times to the End of the Eighteeenth Century. University of California Press, Berkeley.

Greene, B. 2005. Tkanina vesolja. Prostor, čas in tekstura resničnosti. Učila International, založba d.o.o., Tržič, Tržič.

Harvey, D. 1997. Justice, Nature and the Geography of Difference. Blackwell, Oxford.

Lynch, K. 1960. The Image of the City. The MIT Press, Cambridge.

Norberg-Schulz, C. 1984. Genius Loci. Towards a Phenonemlogy of Architecture. Rizzoli, New York.

Plessner, H. 1981. Stupnjevi organskog i čovjek. Uvod u filozofsku antropologiju. Ivo Veselin Masleša, Sarajevo.

Relph, E. 1976. Place and Placelessness. Research and Planning Design, Pion Limited, London.

Scully, V. 1979. The Earth, the Temple, and the Gods. Greek Sacred Architecture. Revised Edition, New Haven, Yale University Press, Westford, Massachusetts.

Thinking space. 2000. Ed. Mike Crang and Nigel Thrift, Toutledge, London.

Tuan, Yi-Fu 1974. Space and Place: Humanistic perspective. Progress in Geography 6, str. 233-246.

Worster, D. 1994. Natures’ Economy. A History of Ecological Ideas. Cambridge Univ. Press., Cambridge 


\section{ABOUT THE SIGNIFICANCE OF LANDSCAPE}

\section{Summary}

Grounding geographical research in philosophy and theory is essential for the discipline because it elaborates a corpus of knowledge, ways of thinking, knowing and doing and provides a hook for empirical work. Geographers must be able to justify the answers that give to our research questions, and that justification cannot avoid philosophical and theoretical ways of knowing. In the article we do not define the landscape and than catalogue how geographers have studied the various bits of landscape referred to its definition. This would treat the landscape as a dictionary where the only interesting issue is how to attach the right words to the right things. The article does not explain the various ways that geographers have studied landscape with the view to determining the best or most accurate mode of investigation. In the article we show that geographers lay claim to understanding of landscape that in our view, tell us something important about landscape. This poses a scientific dilemma. Can all the geographical research of landscape be right, even when our approaches to landscape are poles apart? These questions direct us to a philosophical debate about so-called "realist." and "relativists". The later maintain that absolute truth is impossible since one always understands reality within the particular perceptual or cognitive template. Realists argue that some ways of understanding the world is more objective than others.

The geographer's concept of landscape draws attention to the relation between particularizing and universalising discourses and between subjective and objective perspectives. It refers to the conceptual fusion of space and experience that gives landscape a "wholeness" or an "individuality". To understand landscape requires that we have access to both an objective and subjective reality. From the decentred vantage point of geographical theory, landscape becomes either location or a set of generic relations and thereby loses much of its significance for human action. From the centred point of view, landscape has meaning only in relation to an individual's or group's goals and concerns. Landscape is from the geographical point of view best viewed from points in between (Entrikin, 1991).

It is of course beyond our abilities to resolve the geographical realism-relativism debate. What we aim to do in the article is to show how different philosophical and geographical conceptions of landscape are derived in different ways and mandate different determination on and towards the dimensions of significance of landscape.

It is necessary for geographers to study and to understand the different dimensionality of significance of landscape. In doing this, it is important to examine the more subjective experience of landscape with which we can capture landscape's totality and contextuality and trying to overcome geographical problems about the objective and subjective approaches. 
